\title{
Königshafen: the natural history of an intertidal bay in the Wadden Sea - an introduction
}

\author{
K. Reise ${ }^{1} \&$ C. Gätje ${ }^{2}$ \\ ${ }^{1}$ Biologische Anstalt Helgoland, Wattenmeerstation Sylt; D-25992 List, \\ Federal Republic of Germany \\ ${ }^{2}$ Landesamt für den Nationalpark Schleswig-Holsteinisches Wattenmeer; \\ Schloßgarten 1, D-25832 Tönning, Federal Republic of Germany
}

Volume 48, 2-3 of "Helgoländer Meeresuntersuchungen" is devoted to Königshafen. This is a sheltered intertidal bay of approximately $6 \mathrm{~km}^{2}$, surrounded by sand dunes and salt marshes. It is located at the northern tip of Sylt, a barrier island in the southeastern North Sea. The bay has a long tradition of scientific research. Studying an oyster bed at the mouth of Königshafen, Karl Möbius came up with his now famous concept of a biocoenosis, defined as a community of organisms maintaining equilibrium by mutual interactions (Möbius, 1877). This holistic community concept still survives in the present ecosystem approach.

In the case of the oyster bed it was wrong. Möbius regarded the oyster community as self-sustaining - which it is not (Reise, 1990). Planktonic food is imported by tidal currents, and oyster larvae are exchanged with distant sites. In the coastal zone, exchange processes between communities or habitats are just as important as internal interactions and transformations. This is the research topic of an interdisciplinary project termed SWAP, abbreviation of "Sylter Wattenmeer Austausch-Prozesse" (= Sylt Wadden Sea Exchange Processes) delineating the subject matter under investigation, by its title.

In the case of an imbalance between imports and exports, the coastal ecosystem will undergo a net change in composition. It is the aim of the SWAP-project to quantify exchange processes in an attempt to predict directions of ecological change. Such an endeavour comprises measurements of actual exchange rates of elements and organisms, as well as analyses of past hydrological, morphological and biological changes.

Since the Biologische Anstalt Helgoland founded a research station on the shore of Königshafen in 1924, several scientific studies have been conducted in this bay. The oyster bed studied by Möbius suffered from overexploitation, and vanished in the late 1920s. Only very recently (since 1992), a few individuals of Ostrea edulis have become established again, together with the introduced Japanese Crassostrea gigas. Maps and data provided by Wohlenberg (1937) on sediments, by Nienburg (1927), Hagmeier \& Kändler (1927) and Wohlenberg (1937) on vegetation and benthic fauna allow further comparisons with the present situation. The sediments have apparently become less muddy (Austen, 1992); seagrass, red algae and Sabellaria-reefs have declined in the 


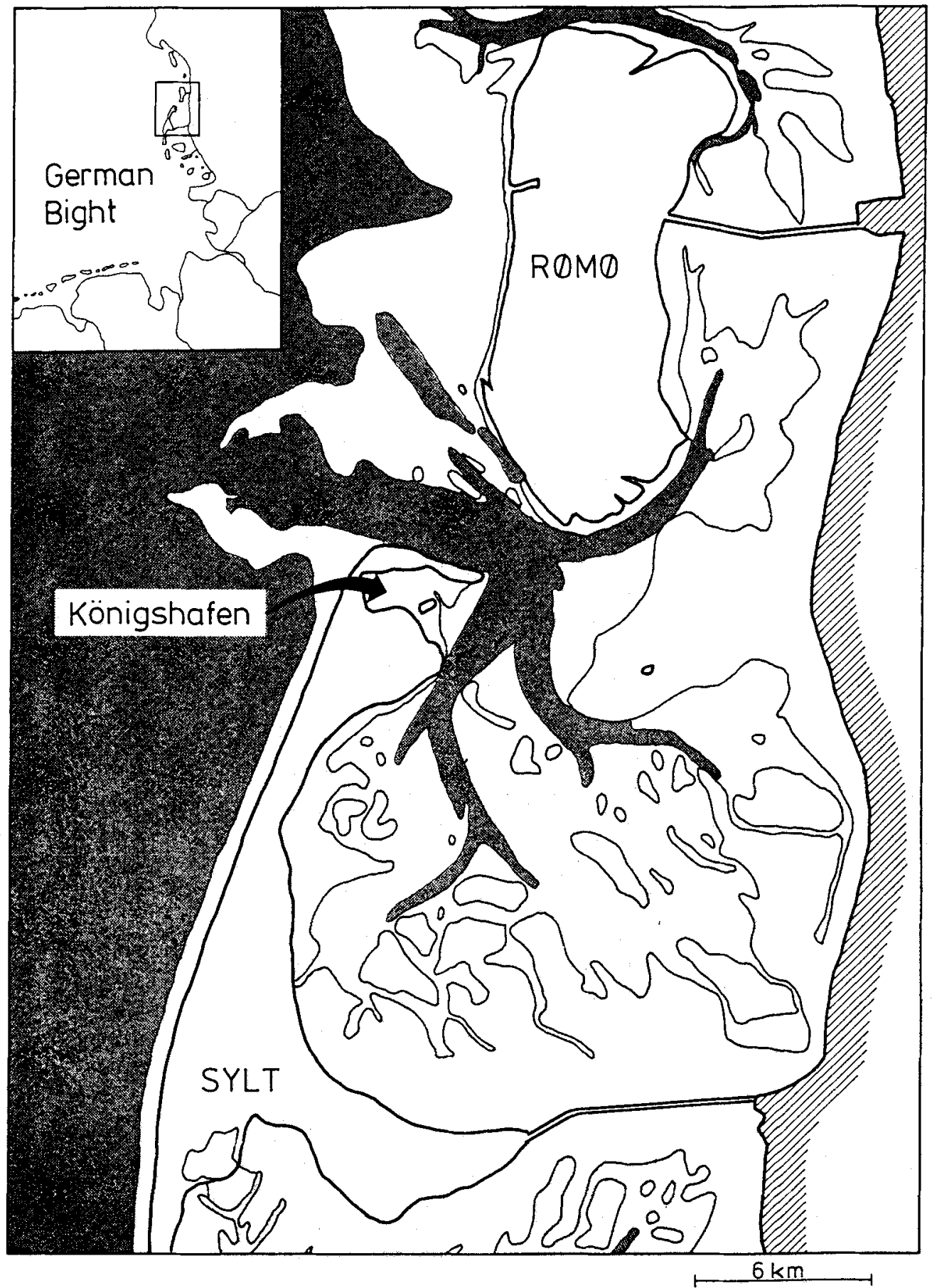

Fig. 1. Wadden Sea region between the islands of Römö and Sylt with Königshafen. Intertidal flats: white area between thick and thin line; subtidal flats: light shading; tidal inlets and North Sea with $>5 \mathrm{~m}$ depth: dark shading; mainland coastline: hatched diagonally 
subtidal zone, while green algae and mussel beds have expanded in the intertidal zone (Reise et al., 1989).

This volume contains research papers prepared from the initial phase of the SWAPproject that concentrated on Königshafen as a small sub-area of the Wadden Sea under investigation, between the islands of Römö and Sylt (Fig. 1). Included are contributions on geological and ecological change, as well as on exchange processes by means of tidal drift.

Acknowledgements. The project "Sylter Wattenmeer Austausch-Prozesse (SWAP)" is funded by the Federal Ministry of Research and Technology (BMFT). SWAP is part of the joint project "Ecosystem Research Wadden Sea", initiated and coordinated by the Regional Office of the National Park Schleswig-Holstein Wadden Sea. Several experts advised us in reviewing manuscripts. The secretarial help of Elisabeth Herre and the help of the copy editors Carol Berger, Andy Godfrey, Elysa Pizzuti and Ellen Wahl are gratefully acknowledged.

\section{LITERATURE CITED}

Austen, I., 1992. Geologisch-sedimentologische Kartierung des Königshafens (List/Sylt). - Meyniana $44,45-52$.

Hagmeier, A. \& Kändler, R., 1927. Neue Untersuchungen im nordfriesischen Wattenmeer und auf den fiskalischen Austernbänken. - Wiss. Meeresunters. (Helgoland) 16, 1-90.

Möbius, K., 1877. Die Auster und die Austernwirthschaft. Wiegandt, Hempel \& Parey, Berlin, 126 pp.

Nienburg, W., 1927. Zur Ökologie der Flora des Wattenmeeres. I. Der Königshafen bei List auf Sylt. - Wiss. Meeresunters. (Kiel) 20, 146-196.

Reise, K., 1990. Karl Möbius: Dredging the first community concept from the bottom of the sea. - Dt. hydrogr. Z. Erg.-H. (Reihe B) 22, 149-152.

Reise, K., Herre, E. \& Sturm, M., 1989. Historical changes in the benthos of the Wadden Sea around the island of Sylt in the North Sea. - Helgoländer Meeresunters. 43, 417-433.

Wohlenberg, E., 1937. Die Wattenmeer-Lebensgemeinschaften im Königshafen von Sylt. - Helgoländer wiss. Meeresunters. 1, 1-92. 